\title{
PERAN KELOMPOKTANI DAN MASYARAKAT PEDULI API (MPA) DALAM MENGELOLA DAN MENCEGAH KEBAKARAN LAHAN DI KECAMATAN BUKIT BATU KABUPATEN BENGKALIS
}

\author{
Wilson Saputra $^{1)}$, Rosnita $^{2)}$, Roza Yulida ${ }^{2)}$ \\ 1. Mahasiswa Agribisnis Fakultas Pertanian Universitas Riau \\ 2. Staf Pengajar Fakultas Pertanian Universitas Riau \\ JL. Binawidya 30, Pekanbaru 28291 \\ E-mail: wilson_utha@yahoo.com
}

\begin{abstract}
ABSTRAK
Tujuan dari penelitian ini adalah: (1) menentukan penyebab kebakaran hutan di Kabupaten Bukit Batu, (2) menganalisis peran kelompok tani dalam mengelola dan mencegah kebakaran hutan di kabupaten Bukit Batu, (3) menganalisis Peran masyarakat konservasi api yang mencegah kebakaran hutan menuju lingkungan keselamatan di kawasan Bukit Batu. Metode yang telah digunakan dalam penelitian ini adalah metode sensus, dan samplingnya purposive. Data analitik ditentukan dengan menggunakan analisis deskriptif dan skala likert. Hasil penelitian menunjukkan: (1) Kebakaran di Kabupaten Bukit Batu disebabkan oleh faktor biofisik, faktor ekonomi dan faktor sosial budaya. (2) Peran kelompok tani dalam mengelola dan mencegah kebakaran hutan menjadi kategori yang sangat diperhatikan. (3) Peran masyarakat konservasi api dalam mencegah kebakaran hutan juga dalam kategori tinggi.
\end{abstract}

Kata kunci: Peran kelompok tani, Komunitas Pemadam Kebakaran

\section{PENDAHULUAN}

Provinsi Riau adalah salah satu dari delapan propinsi di Sumatera yang terletak di bagian timur yang sebagian besar merupakan dataran rendah. Dari luas daratan Provinsi Riau 9,4 juta ha, atau sekitar 40\% (3,9 juta ha) diantaranya adalah merupakan dataran rendah yang bergambut dan sebagian diantaranya dipengaruhi oleh pasang surut.Eksploitasi sumber daya hutan secara besar-besaran pada dua dekade terakhir di Provinsi Riau telah mengubah tata guna lahan dari kawasan hutan yang utuh menjadi kawasan perkebunan dan transmigrasi, terutama di lahan kering dan pasang surut dengan luas mencapai lebih dari 2 juta ha. Hal ini menyebabkan semakin terbatasnya lahan kering dalam 5 tahun terakhir, investor perkebunan dan Hutan Tanaman Industri (HTI) mulai mengarah ke lahan basah/bergambut.

Kabupaten Bengkalis merupakan kabupaten yang menyumbang asap dengan lahan kebakaran yang terluas di Provinsi Riau pada tahun 2014 (Badan Lingkungan Hidup Provinsi Riau). Kebakaran besar di Kabupaten Bengkalis

57 Peran Kelompok Tani Dan Masyarakat Peduli Api (MPA) Dalam Mengelola Dan Mencegah Kebakaran Lahan Di Kecamatan Bukit Batu Kabupaten Bengkalis 
sebagian besar terjadi di Kecamatan Bukit Batu, sejak kebakaran besar tersebut Bukit Batu menjadi sorotan nasional maupun internasional dalam kerusakan hutan rawa gambut. Bukit Batu yang merupakan salah satu Kecamatan di Kabupaten Bengkalis dengan luas wilayah hampir 2 kali lebih besar dari negara Singapura $\left(699 \mathrm{~km}^{2}\right.$ ), menjadi sentra perekonomian berbasis lingkungan percontohan di Kabupaten Bengkalis Provinsi Riau.

Pada tahun 2012-2015, Kecamatan Bukit Batu menyumbangkan asap hingga ke negeri tetangga khususnya Singapore dan Malaysia yang disebabkan oleh kebakaran lahan gambut yang hebat. Kebakaran yang terjadi di wilayah ini hampir terjadi setiap tahunnya. Beberapa desa di Kecamatan Bukit Batu selalu terjadi kebakaran hutan dan lahan (karhutla), kondisi ini disebabkan kawasan ini memiliki struktur tanah gambut.Berikut adalah titik panas dalam 3 (tiga) tahun terakhir pada Kabupaten Bengkalis dapat dilihat pada Tabel 1.

Tabel 1. Titik panas Kabupaten Bengkalis

\begin{tabular}{ccc}
\hline Tahun & Riau & Bengkalis \\
\hline 2013 & 4419 & 1098 \\
2014 & 6056 & 2972 \\
2015 & 2198 & 156 \\
\hline Jumlah & 12673 & 4262 \\
\hline \multicolumn{2}{l}{ Sumber : Badan Meteorologi Klimatologi dan Geofisika (BMKG) }
\end{tabular}

Kawasan hutan di kecamatan ini sudah beralih fungsi menjadi areal perkebunan kelapa sawit dan karet, mayoritasmasyarakat berusahadalam sektor perkebunan kelapa sawit disamping karet.Dalam sistem penyiapan lahan atau alih fungsilahan,masyarakat Kecamatan Bukit Batu menggunakan metode dengan cara membakar lahan untuk membersihkanlahandari semak-semak.

Masyarakat khususnya kelompoktani dan MPA sebagai pihak yang berada paling dekat yang berdampak langsung dengan kebakaran yang ada bisa menjadi jalan keluar. Pemerintah pusat dan pemerintah daerah akan berada di lokasi ketika bencana terjadi, namun setelah bisa mengatasi, mereka pun akan segera pergi. Dengan demikian, kelompoktanidan Masyarakat Peduli Api (MPA) yang senantiasa berada di lokasi hendaknya bisa mencegah pembakaran lahan dan hutan agar tidak menjadi bencana. Peran kelompoktanidan MPA untuk mencegah terjadinya bencana kebakaran lahan dan hutan bisa dimulai dari tingkat desa.

Berdasarkan uraian latar belakang tersebut maka tujuan penelitian ini adalah : Mengetahui penyebab kebakaran di Kecamatan Bukit Batu, menganalisis peran 58 | Peran Kelompok Tani Dan Masyarakat Peduli Api (MPA) Dalam Mengelola Dan Mencegah Kebakaran Lahan Di Kecamatan Bukit Batu Kabupaten Bengkalis 
kelompoktani dalam mengelola dan mencegah kebakaran lahan, menganalisis peran masyarakat peduli api dalam mencegah kebakaran lahan di Kecamatan Bukit Batu.

\section{METODE PENELITIAN}

\section{Tempat dan Waktu Penelitian}

Penelitian ini dilaksanakan di Desa Sepahat dan Desa Tanjung Leban Kecamatan Bukit Batu Kabupaten Bengkalis. Pemilihan lokasi penelitian dilakukan secara sengaja (purposive) dengan pertimbangan bahwa Kecamatan Bukit Batu merupakan salah satu kecamatan yang mengalami kebakaran lahan besar di Kabupaten Bengkalis. Desa Sepahat dan Desa Tanjung Leban yang ada di Kecamatan Bukit Batu merupakan Desa yang memiliki kelompoktani dan Masyarakat Peduli Api (MPA). Penelitian ini dilakukan selama 8 bulan pada Bulan Januari 2016 sampai Agustus 2016 dari pembuatan proposal, survei di lapangan untuk pengumpulan data, pengolahan data dan skripsi serta jurnal sebagai hasil akhir dari penelitian.

\section{Metode Pengambilan Sampel dan Data}

Responden diambil dengan metode sensus, dimana memilih kelompoktani dan MPA yang bergerak dalam mencegah kebakaran lahan di Kecamatan Bukit Batu. Kelompoktani tersebut terdiri dari 4 kelompoktani dengan total responden 78 orang petani dan MPA terdiri dari 2 desa dengan total responden 34 orang .

Teknik pengambilan data menggunakan metode survei, untuk data primer dengan melakukan wawancara menggunakan kuesioner yang telah dibuat sebelumnya sesuai tujuan penelitian, sedangkan data sekunder diperoleh dari instansi terkait seperti Kantor Camat Bukit Batu, Dinas Perkebunan Kabupaten Bukit Batu, Badan Pusat Statistik serta studi penelitian terdahulu, jurnal, dan buku literatur.

\section{Analisis Data}

Data yang telah diperoleh akan dianalisis dengan menggunakan metode deskiptif kualitatif dan analisis kuantitatif, untuk menganalisis bagaimana peran kelompoktani dan MPA dengan menggunakan skala likert dengan rentang skala:

1. Rendah $(\mathrm{R})=1,00-1,66$

2. $\operatorname{Cukup}(\mathrm{C})=1,67-2,33$

3. Tinggi $(\mathrm{T})=2,34-3,00$

59 | Peran Kelompok Tani Dan Masyarakat Peduli Api (MPA) Dalam Mengelola Dan Mencegah Kebakaran Lahan Di Kecamatan Bukit Batu Kabupaten Bengkalis 


\section{HASIL DAN PEMBAHASAN}

\section{Penyebab Kebakaran}

Penggunaan api dalam aktifitas manusia merupakan penyebab utama yang langsung mengakibatkan kebakaran hutan dan lahan di Kecamatan Bukit Batu. Penyebab kebakaran didukung oleh 3 aspek yaitu aspek biofisik, aspek ekonomi, dan aspek sosial budaya.

\section{a. Aspek Biofisik}

Unsur-unsur iklim/cuaca menentukan kadar air dan kemudahan terbakar serta mempengaruhi penyebaran api. Hutan secara alami sulit terbakar, tetapi pada saat terjadi kekeringan hutan sekunder dapat menghasilkan bahan bakaran karena adanya serasah dan tumbuhan bawah yang sangat kering sehingga meningkatkan resiko kebakaran hutan dan lahan. Demikian pula hutan yang telah dikonversi dan berubah menjadi alang-alang atau belukar akan lebih mudah terbakar dibandingkan dengan hutan alam. Saat musim kemarau panjang sering terjadi merembetnya api dari desa tetangga. Desa Sepahat dan Desa Tanjung Leban adalah desa yang bersebelahan dan sama sama memiliki lahan yang luas, saat kebakaran besar sering terjadi merembetnya api dari Desa Sepahat ke Tanjung Leban dan sering juga sebaliknya. Dalam hal ini El Nino adalah sebagai penyebab kekeringan, sehingga mempercepat pengeringan bahan bakar dan jika kebakaran sudah terjadi akan mempercepat penjalarannya. Kecamatan Bukit Batu adalah kecamatan yang secara geografis berbatasan langsung dengan selat malaka. Sepanjang kelurahan atau desa Pangkalan Jambi sampai Tanjung Leban berbatasan langsung dengan garis pantai, ketika terjadi kebakaran hutan dan lahan di kecamatan ini tiupan angin laut dapat mempercepat penjalaran api di siang hari.

Kecamatan Bukit Batu memiliki lahan gambut yang sangat luas, lebih dari 80\% lahan Bukit Batu bergambut, terutama di Desa Sepahat dan Desa Tanjung Leban memiliki kedalaman gambut ditaksir rata-rata diatas 7,5 meter yang tergolong gambut sangat dalam. Dari hasil wawancara di lapangan dengan Kepala Desa Sepahat menyebutkan pada kondisi alami, lahan gambut tidak mudah terbakar karena sifatnya yang menyerupai spons, yakni menyerap dan menahan air secara maksimal. Ini yang menyebabkan pada musim hujan dan musim kemarau jumlah cadangan air tidak ekstrem. Namun, apabila kondisi lahan gambut sudah mulai terganggu akibat konversi lahan atau pembuatan kanal maka

60 Peran Kelompok Tani Dan Masyarakat Peduli Api (MPA) Dalam Mengelola Dan Mencegah Kebakaran Lahan Di Kecamatan Bukit Batu Kabupaten Bengkalis 
keseimbangan ekologis tanah akan terganggu. Saat musim kemarau panjang lahan gambut mengering mudah terbakar dan menimbulkan asap tebal. Jika sudah terlanjur terbakar api di lahan gambut sangat sulit dipadamkan karena lahan gambut akan sangat mengering sampai kedalaman tertentu. Sisa gambut di bawah permukaan menjadi semacam bahan bakar sehingga api yang tampak padam di permukaan tidak berarti api benar-benar padam. Di bawah permukaan tanah, secara lambat bara api tetap menyala sehingga sulit terdeteksi.

Kerusakan yang disebabkan oleh konversi lahan bersifat permanen akibat adanya penurunan permukaan lapisan gambut (subsidence).Penurunan terjadi akibat pembangunan kanal-kanal disekitar areal perkebunan kelapa sawit yang bertujuan mengalirkan air. Kekeringan gambut permukaan akan memicu terjadinya kebakaran lahan gambut pada musim kemarau.Kerusakan yang disebabkan oleh kebakaran hutan dan lahan menyebabkan kerusakan hutan dalam skala luas. Hal tersebut juga didukung oleh tersedianya bahan bakar pada gambut seperti kandungan bahan organik dan serasah yang menyebabkan api merembet sangat cepat pada saat kondisi gambut yang kering terutama pada musim kemarau.Penurunan permukaan lapisan gambut berkorelasi positif dengan penurunan muka air. Semakin dalam titik turunnya permukaan air menyebabkan kadar air yang terkandung pada permukaan lahan gambut semakin berkurang, sehingga gambut permukaan menjadi kering. Hal itulah yang mengakibatkan apabila terjadi kebakaran akan semakin bersar kemungkinan merembetnya api kedalam lapisan gambut. Kebakaran dibawah permukaan gambut itu dikenal dengan ground fire.

\section{b. Aspek Ekonomi}

Pendapatan rumah tangga adalah pendapatan atau penghasilan yang diterima oleh rumah tangga bersangkutan baik yang berasal dari pendapatan kepala rumah tangga maupun anggota rumah tangga itu sendiri.Dampak dari kurangnya jumlah pendapatan tersebut menyebabkan masyarakat membuka lahan dengan cara membakar dikarenakan besarnya biaya pembukaan lahan tanpa bakar. Menurut Anonimous dalam Suharyani (2012) pembukaan lahan dengan pembakaran hanya membutuhkan waktu 28 HOK (hari orang kerja), sementara pembukaan lahan secara mekanis untuk hutan primer membutuhkan 80 HOK ditambah 12 jam kerja traktor, untuk hutan sekunder diperlukan 53 HOK ditambah 10 jam traktor. Mencegah Kebakaran Lahan Di Kecamatan Bukit Batu Kabupaten Bengkalis 
Berdasarkan Pedoman Pembukaan Lahan Tanpa Bakar (PLTB) yang dikeluarkan Direktorat Perlindungan Perkebunan tahun 2013, diperlukan waktu 48 hari kerja untuk membersihkan semak berlukar dengan tenaga manusia. Setiap hektarnya mengeluarkan biaya $\mathrm{Rp} 2.400 .000$, ditambah dengan traktor selama enam hari memakan biaya Rp 1.200.000 per hektar. Total pembukaan lahan tanpa bakar memakan biaya Rp 3.600.000 per hektar.Sehingga pembukaan lahan dengan cara membakar menjadi solusi tepat ditengah perekonomian masyarakat Bukit Batu yang tergolong sedang yang pendapatannya berkisar antara Rp.1.000.000 Rp.4.000.000 dan hanya cukup untuk memenuhi kebutuhan sehari-hari.

Status kepemilikan lahan menjadi salah satu penyebab kebakaran lahan di Kecamatan Bukit Batu, umumnya lahan yang dimiliki masyarakat Desa Sepahat dan Desa Tanjung Leban adalah lahan hak milik sendiri. Dari hasil wawancara yang dilakukan dengan responden mengatakan bahwa hak milik lahan yang dikuasai adalah milik sendiri sehingga responden berani melakukan pembukaan lahan dengan cara membakar. Aktifitas masyarakat dalam membersihkan maupun membuka lahan dengan cara membakar merupakan hal yang biasa saja dan sudah dilakukan dari dahulu baik itu membakar ranting di sekitar lahan maupun ilalang yang menjadi permasalahannya yaitu kegiatan tersebut kurang dikontrol oleh masyarakat sehingga mengakibatkan kebakaran yang tidak terkendali. Kepemilikan lahan oleh orang dari luar desa atau kecamatan juga menyebabkan banyaknya lahan tidur atau lahan yang tidak terurus, lahan tidur yang bersemak dan kering sering membuat api yang besar dan menjalar ke sekelilingnya.

Luas lahan yang dimiliki masyarakat menjadi salah satu faktor penyebab kebakaran lahan, dikarenakan luas lahan menentukan pengambilan keputusan dalam membuka lahan dengan cara membakar atau tanpa bakar. Berdasarkan wawancara di lapangan, petani Desa Sepahat dan Desa Tanjung Leban rata-rata memiliki luas 3 hektar persegi. Semakin luas lahan yang dimiliki dan dibuka untuk usahatani akan semakin besar kemungkinan masyarakat melakukan membuka lahan dengan cara membakar dan begitu juga sebaliknya, hal ini dikarenakan nilai ekonomi dalam pembukaan lahan dengan cara membakar tergolong murah dan dari segi waktu tergolong cepat dan mudah.

$62 \mid$ Peran Kelompok Tani Dan Masyarakat Peduli Api (MPA) Dalam Mengelola Dan Mencegah Kebakaran Lahan Di Kecamatan Bukit Batu Kabupaten Bengkalis 


\section{c. Aspek Sosial Budaya}

Faktor tingkat pendidikan menjadi salah satu penyebab kebakaran di Kecamatan Bukit Batu dikarenakan kurangnya pengetahuan masyarakat tentang dampak dari membakar lahan baik itu terhadap kesuburan maupun dampak yang lainnya.Rendahnya pengetahuan penduduk khususnya tentang ilmu lingkungan dan pembangunan berkelanjutan mengakibatkan masyarakat tidak memiliki pandangan angka panjang dalam pengelolaan lingkungan, salah satunya dalam kegiatan pertanian dan perkebunan. Akibat rendahnya pengetahuan penduduk tentang pandangan jangka panjang dalam pengelolaan lingkungan hidup, maka masyarakat dalam proses pembukaan lahan tanpa memperlihatkan karakteristik dari lahan yang dibakar terutama pada lahan gambut sehingga pada saat pembukaan lahan dengan cara membakar dapat mengakibatkan kebakaran lahan tak terkendali.

Masyarakat Kecamatan Bukit Batu sebagian besar bersuku dan berbudaya melayu yang dahulu banyak melakukan perladangan berpindah dengan sistem rotasi. Masyarakat melayu turun menurun dalam membuka lahan dengan cara membakar semak belukar secara bertahap dan dalam skala kecil agar pembakaran lahan benar-benar diperhitungkan dan dijaga apinya. Kegiatan membuka lahan dengan cara membakar sudah ada sejak zaman dahulu dan bukan hal yang mudah untuk menghilangkan budaya membakar tersebut, sebab dengan cara pembakaran dianggap paling efektif dan mudah untuk dilakukan. Namun yang jadi permasalahannya sekarang sering lalainya penduduk dalam membersihkan maupun membuka lahan dengan cara membakar kurang dikontrol sehingga mengakibatkan kebakaran lahan yang tidak terkendali dan sering mengakibatkan kerugian para petani itu sendiri yang lahan usahataninya terbakar secara tidak sengaja.

Kecamatan Bukit Batu memiliki perusahaan HTI yang memiliki izin konsesi hak pengusahaan hutan tanaman industri (HTI) dengan komoditas tanaman kayu akasia. Penyebab kebakaran yang terjadi di Riau dalam dua dekade terakhir tidak lepas dari dugaan berdirinya perusahaan HTI, dalam pembukaan lahan maupun perluasan lahan perusahaan diduga membuka lahan dengan cara membakar. Kebakaran besar yang terjadi pada tahun 2014 juga membakar sebagian lahan 
perusahaan HTI di kecamatan ini, hal ini juga mengindikasikan adanya kemungkinan perusahaan menjadi penyebab kebakaran di Kecamatan Bukit Batu.

Pemerintah Provinsi Riau kurang serius dalam penanganan bencana asap. Pemerintah kurang tegas dalam memberi sanksi pelaku pembakaran hutan termasuk perusahaan swasta yang diduga terlibat. Kurang tegasnya Pemprov Riau terlihat dari pembukaan lahan untuk perusahaan perkebunan kelapa sawit.Menteri Lingkungan Hidup dan Kehutanan Siti Nurbaya mengatakan kelemahan dalam penegakan hukum perkara kebakaran hutan dan lahan di Indonesia umumnya terkait hukum acara dan prosedur dalam memproses perkara perdata maupun pidana perusahaan pelaku pembakaran hutan atau lahan menjadi celah kebiasaan buruk perusahaan maupun masyarakat yang membuka lahan dengan cara membakar. Mencari pelaku pembakaran sampai saat ini masih sulit untuk diketahui, karena masih kurang pengawasan di hutan dan lahan.Tidak adanya polisi hutan di Kecamatan Bukit Batu juga menjadi celah untuk pelaku pembakaran.

\section{Peran Kelompoktani}

Peran kelompoktani dalam menjaga dan mencegah kebakaran lahan sangat penting agar terhindar dari kebakaran hutan dan lahan yang mengancam usahataninya.Peran kelompoktani dalam mengelola dan mencegah kebakaran lahan di Kecamatan Bukit Batu dapat diukur dari variabel kelas belajar, kerjasama dan unit produksi. (Peraturan Menteri Pertanian Nomor 82 / Permentan / OT.14 / 08 /2013 Peningkatan Kemampuan Kelompoktani dalam Menjalankan Fungsinya)

\section{a. Wadah Kelas Belajar}

Kelompok tani sebagai wadah kelas belajar merupakan sarana dalam membangun hubungan dan pengetahuan kelompok tani dalam kegiatan pengelolaan dan pencegahan kebakaran lahan di lokasi usahataninya. Hasil peran kelompok tani sebagai wadah kelas belajar bagi anggota kelompok tani untuk lebih jelasnya dapat dilihat pada Tabel 2.

Tabel 2. Peran kelompoktani sebagai wadah kelas belajar di Kecamatan Bukit Batu

\begin{tabular}{llcc}
\multicolumn{1}{c}{ Batu } & \multicolumn{1}{c}{ Indikator } & Skor & Kategori \\
\hline No. & \multicolumn{1}{c}{ Kenggali dan Merumuskan Kebutuhan Belajar } & Tinggi \\
2 & Merencanakan dan Mempersiapkan Kebutuhan Belajar & 2,61 & Tinggi \\
3 & Kedisiplinan dan Motivasi Anggota Kelompok & 2,58 & Tinggi \\
4 & Melaksanakan Pertemuan dan Pembelajaran & 2,39 & Tinggi \\
5 & Menjalin Kerjasama dengan Sumber Informasi yang diperlukan dalam & 2,42 & Tinggi \\
& proses belajar & & \\
\hline
\end{tabular}

64 Peran Kelompok Tani Dan Masyarakat Peduli Api (MPA) Dalam Mengelola Dan Mencegah Kebakaran Lahan Di Kecamatan Bukit Batu Kabupaten Bengkalis 


\begin{tabular}{llcc}
\hline 6 & Lingkungan Belajar & 2,57 & Tinggi \\
7 & Keaktifan dalam Kegiatan Belajar & 2,36 & Tinggi \\
8 & Memahami Keinginan dan Pendapat maupun masalah anggota kelompok & 2,68 & Tinggi \\
9 & $\begin{array}{l}\text { Merumuskan Kesepakatan Bersama dalam Memecahkan Masalah dan } \\
\text { Melakukan Kegiatan }\end{array}$ & 2,49 & Tinggi \\
\hline & & Rata-rata & 2,53 \\
\hline
\end{tabular}

Tabel 2 menunjukkan hasil variabel peran kelompoktani sebagai kelas belajar di Kecamatan Bukit Batutermasuk dalam kategori "Tinggi”, dimana skor ratarata yang diperoleh sebesar 2,53. Hal ini menjelaskan bahwa kelompoktani sudah berperan sebagai wadah bagi anggota untuk saling belajar satu sama lain. Semua indikator berkategori tinggi namun pada indikator nomor lima (5) masih kurang aktifnya anggota dalam kegiatan belajar, hal ini seperti tidak hadirnya anggota dan juga kurang aktif dalam diskusi.Kelompoktani mampu menumbuhkan aktivitas kelas belajar bagi kelompoknya dengan mendatangkan bantuan pengajar dari luar kelompoktani, seperti lembaga penyuluh pertanian dan Masyarakat Peduli Api. Selain itu, kelompoktani mempersiapkan materi-materi yang dibutuhkan oleh anggota dengan bantuan lembaga penyuluh.

\section{b. Wahana Kerjasama}

Kelompoktani sebagai lembaga media kerjasama merupakan wadah dan sarana dalam membangun relasi untuk memenuhi kebutuhan dalam kegiatan pengelolaan dan pencegahan kebakaran yang dijalankan anggotanya. Selain itu, untuk menjalankan perannya sebagai wahana kerjasama bagi anggota kelompok, pengurus kelompok harus mampu memperkuat, memperlancar dan sekaligus mendorong terwujudnya kerjasama yang saling menguntungkan, baik antar anggota kelompoktani maupun dengan pihak lain. Hasil peran kelompoktani sebagai wahana kerjasama bagi anggota kelompoktani untuk lebih jelasnya dapat dilihat pada Tabel 3 .

Tabel 3 menunjukkan semua indikator wahana kerjasama kelompoktani memperoleh kategori "Tinggi", hal ini menjelaskan bahwa kelompoktani telah melakukan kegiatan kerjasama antar anggota dan antar pihak lain, baik itu dalam kegiatan antar kelompoktani maupun kegiatan untuk memenuhi kebutuhan usahatani anggota.

Tabel 3. Peran kelompoktani sebagai wahana kerjasama di Kecamatan Bukit Batu

\begin{tabular}{llll}
\hline No & \multicolumn{1}{c}{ Indikator } & Skor & Kategori \\
\hline 1 & Menciptakan Suasana Kerjasama & 2,64 & Tinggi \\
2 & Menciptakan Suasana Keterbukaan dalam Kelompok & 2,56 & Tinggi \\
\hline
\end{tabular}

$65 \mid$ Peran Kelompok Tani Dan Masyarakat Peduli Api (MPA) Dalam Mengelola Dan Mencegah Kebakaran Lahan Di Kecamatan Bukit Batu Kabupaten Bengkalis 


\begin{tabular}{|c|c|c|c|}
\hline 3 & Pembagian Tugas Antar Anggota Kelompok & 2.50 & Tinggi \\
\hline 4 & $\begin{array}{l}\text { Kedisiplinan dan Rasa Tanggung Jawab Antar Anggota } \\
\text { Kelompok }\end{array}$ & 2,48 & Tinggi \\
\hline 5 & Merencanakan dan Melaksanakan Musyawarah Kelompok & 2,59 & Tinggi \\
\hline 6 & Melaksanakan Kerjasama Penyediaan Sarana dan Jasa Pertanian & 2,58 & Tinggi \\
\hline 7 & Kegiatan Pelestarian Lingkungan & 2,65 & Tinggi \\
\hline 8 & Mentaati Kesepakatan Antara Kelompok dan Pihak Lain & 2,44 & Tinggi \\
\hline 9 & $\begin{array}{l}\text { Kerjasama dan Kemitraan dengan Pihak Penyedia Sarana } \\
\text { Produksi }\end{array}$ & 2,72 & Tinggi \\
\hline 10 & Ketersediaan Modal & 2,46 & Tinggi \\
\hline \multicolumn{2}{|r|}{ Rata-rata } & 2,56 & Tinggi \\
\hline
\end{tabular}

Ada kekurangan pada indikator mentaati kesepakatan bersama antar kelompok dan indikator ketersediaan modal. Keadaan ini dikarenakan anggota belum mampu mentaati kesepakatan jadwal pertemuan dan peraturan dalam kegiatanusaha tani dan pencegahan kebakaran, selain itu kelompoktani kurang mampu memenuhi keuangan bagi anggota dan dibutuhkan kemitraan dengan lembaga permodalan agar keuangan terpenuhi untuk membantu para anggota.

\section{c. Wahana Unit Produksi}

Peran kelompoktani sebagai penyedia unit produksi adalah kemampuan kelompok dalam menyediakan sarana dan prasarana dalam menunjang kegiatan anggotanya, sehingga mampu meningkatkan skala ekonomis usaha yang dijalankan oleh kelompok maupun anggota kelompok dengan menjaga kuantitas maupun kontinuitas. Hasil peran kelompoktani sebagai wahanaunit produksi untuk lebih jelasnya dapat dilihat pada Tabel 4.

$\underline{\text { Tabel 4. Kelompoktani sebagai wahana unit produksi di Kecamatan Bukit Batu }}$

\begin{tabular}{llll}
\hline No & \multicolumn{1}{c}{ Indikator } & Skor & Kategori \\
\hline 1 & Pengambilan Keputusan dalam Pengembangan Produksi & 2,58 & Tinggi \\
2 & Menyusun dan Melaksanakan Kebutuhan Poktan & 2,49 & Tinggi \\
3 & Memfasilitasi Penerapan Teknologi (bahan, alat, cara) bagi & 2,22 & Cukup \\
4 & Anggota Kelompok & 2,48 & Tinggi \\
5 & Menjalin Kerjasama Kemitraan Terkait Unit Produksi & 2,49 & Tinggi \\
6 & Mentaati dan Melaksanakan Kesepakatan yang telah dibuat & 2,38 & Tinggi \\
\hline & Rata-rata & 2,44 & Tinggi \\
\hline
\end{tabular}

Tabel 4 menunjukkan dari enam (6) ada lima (5) indikator memperoleh skor dengan kategori "Tinggi" hanya indikator memfasilitasi penerapan teknologi (bahan, alat, cara) bagi anggota kelompok yang berkategori "Cukup", artinya kelompoktani mampu menjalankan semua tugasnya sebagai wahana unit Mencegah Kebakaran Lahan Di Kecamatan Bukit Batu Kabupaten Bengkalis 
produksi, akan tetapi dalam pelaksanaannya ada beberapa kegiatan kelompoktani yang belum mampu dilakukan seperti pengadministrasian yang baik dalam kegiatan maupun keuangannya, sehingga kelompoktani tidak memiliki pembukuan yang baik. Ketersediaan modal yang minim dimiliki oleh kelompoktani sendiri mengakibatkan kurangnya pinjaman modal bagi para anggota, sehingga dibutuhkan kegiatan pemupukan modal yang lebih baik agar kelompoktani mampu memenuhi modal bagi anggotanya, seperti meningkatkan iuran kelompoktani maupun memperluas kerjasama dengan lembaga penyediaan modal.

\section{Peran Masyarakat Peduli Api (MPA)}

Masyarakat Peduli Api (MPA) adalah kelompok bagi masyarakat pedesaan yang tergabung dari berbagai profesi mempunyai kepedulian terhadap kelestarian hutan dan terhadap pengendalian kebakaran hutan dan lahan dengan sukarela menyatakan kesediaannya untuk melakukan pengendalian sesuai dengan keahlian dan keterampilan. Peran MPA dalam penelitian ini diukur dari variabel memberikan informasi, menyebarluaskan informasi, melakukan penyuluhan, dan melakukan pertemuan.

\section{a. Memberikan Informasi}

Memberikan informasi adalah peran yang dimiliki oleh MPA sebagai petugas yang berasal dari masyarakat setempat dalam memberikan informasi terkait kejadian kebakaran lahan, sehingga kebakaran bisa ditanggulangi secara cepat.Hasil peran MPA dalam memberikan informasi untuk lebih jelasnya dapat dilihat pada Tabel 5 .

Tabel 5. MPA memberikan informasi di Kecamatan Bukit Batu

\begin{tabular}{|c|c|c|c|}
\hline No & Indikator & Skor & Kategori \\
\hline 1 & $\begin{array}{llll}\begin{array}{l}\text { Memberikan } \\
\text { kebakaran }\end{array} & \text { informasi } & \text { terkait } & \text { kejadian } \\
\end{array}$ & 2,77 & Tinggi \\
\hline 2 & $\begin{array}{l}\text { Memberikan informasi terkait pelaku } \\
\text { pembakaran }\end{array}$ & 2,71 & Tinggi \\
\hline 3 & $\begin{array}{l}\text { Memberikan informasi kepada kepolian terkait } \\
\text { kebakaran }\end{array}$ & 2,53 & Tinggi \\
\hline & Rata-rata & 2,67 & Tinggi \\
\hline
\end{tabular}

Tabel 5 menunjukkan semua indikator berkategori "Tinggi" dengan skor ratarata 2,67, artinya artinya MPA telah memberikan informasi antar anggota dan pihak lain. Kerjasama dalam bertugas sebagai MPA berjalan baik, ini terlihat dari koordinasi tim di posko MPA dengan tim yang sedang berpatroli. Setiap

67 Peran Kelompok Tani Dan Masyarakat Peduli Api (MPA) Dalam Mengelola Dan Mencegah Kebakaran Lahan Di Kecamatan Bukit Batu Kabupaten Bengkalis 
menemukan titik api informasi langsung diberikan kepada tim yang berada di posko MPA mengenai posisi lokasi, besaran titik api dan penyebab terbakar. Anggota MPA yang berada di posko langsung turun ke lokasi terbakar membawa alat pemadam dan api segera dipadamkan.Skor terendah MPA ini ada pada indikator memberikan informasi kepada kepolisian terkait kejadian kebakaran dan pelaku pembakaran, hal ini dikarenakan jarak antara kantor polisi dengan lokasi desa lumayan jauh yang berjarak $45 \mathrm{~km}$. Sehingga informasi dan pencarian pelaku pembakaran susah didapatkan.

\section{b. Menyebarluaskan Informasi}

Masyarakat Peduli Api dalam perannya menyebarluaskan informasi adalah tugas utama MPA sebagai pihak terdekat dengan masyarakat untuk menyebarluaskan informasi terkait penyebab, cara pencegahan, cara penanggulangan, dan dampak akibat dari kebakaran lahan. Hal ini sangat penting agar kebakaran tidak terjadi terus menerus di Provinsi Riau.Hasil penelitian peran MPA dalam menyebarluaskan informasi untuk lebih jelasnya dapat dilihat pada Tabel 6.

Tabel 6. MPA menyebarluaskan informasi di Kecamatan Bukit Batu

\begin{tabular}{llcc}
\hline No & \multicolumn{1}{c}{ Indikator } & Skor & Kategori \\
\hline 1 & Menyebarluaskan informasi penyebab kebakaran & 2,67 & Tinggi \\
2 & Menyebarluaskan informasi pencegahan kebakaran & 2,91 & Tinggi \\
3 & Menyebarluaskan informasi penanggulangan kebakaran & 2,79 & Tinggi \\
4 & Menyebarluaskan informasi dampak kebakaran & 2,79 & Tinggi \\
\hline & Rata-rata & 2,79 & Tinggi \\
\hline
\end{tabular}

Tabel 6 menunjukkan semua indikator berkategori "Tinggi". Nilai tersebut menjelaskan bahwa MPA selalu menginformasikan kepada warga desa mengenai penyebab, penanggulangan, pelaku, dan dampak dari kebakaran yang terjadi di desa hal ini terbukti dari berkurangnya dari 2972 menjadi 156 jumlah titik api pada tahun 2015. Kebakaran tidak hanya tanggung jawab bagi MPA tapi juga tanggung jawab bersama, artinya MPA butuh kerjasama dengan warga untuk menjaga dan melestarikan alam, akan tetapi masih ada oknum yang tidak bertanggungjawab yang dengan sengaja membakar lahan. Sehingga perlu kesadaran akan dampak dan bahaya dari kebakaran hutan dan lahan. Skor terendah ada pada indikator menyebarluaskan informasi penyebab kebakaran

$68 \mid$ Peran Kelompok Tani Dan Masyarakat Peduli Api (MPA) Dalam Mengelola Dan Mencegah Kebakaran Lahan Di Kecamatan Bukit Batu Kabupaten Bengkalis 
lahan, hal ini dikarenakan sebab terbakar sulit diketahui secara langsung, tetapi pada umumnya penyebab kebakaran dikarenakan faktor manusia yang sengaja maupun tidak sengaja.

\section{c. Melakukan Penyuluhan}

Melakukan penyuluhan adalah peran yang dimiliki oleh MPA sebagai masyarakat yang berada di desa berkecimpung di kegiatan dalam menjaga kelestarian alam dari kebakaran hutan dan lahan untuk meningkatkan kesadaran masyarakat agar tidak melakukan pembakaran.Hasil penelitian peran MPA dalam melakukan penyuluhan untuk lebih jelasnya dapat dilihat pada Tabel 7.

Tabel 7. MPA melakukan penyuluhan di Kecamatan Bukit Batu

\begin{tabular}{llcc}
\hline No & \multicolumn{1}{c}{ Indikator } & Skor & Kategori \\
\hline 1 & Penyuluhan bersama petugas unit & 2,49 & Tinggi \\
2 & Menggalang meningkatkan kesadaran masyarakat & 2,62 & Tinggi \\
3 & Pengenalan peralatan pemadaman & 2,64 & Tinggi \\
4 & Menjelaskan indikator penyebab kebakaran & 2,76 & Tinggi \\
5 & Penggunaan peralatan tangan untuk pemadaman & 2,73 & Tinggi \\
6 & Menjelaskan dasar hukum bagi pelaku pembakaran & 2,59 & Tinggi \\
\hline & Rata-rata & 2,64 & Tinggi \\
\hline
\end{tabular}

Tabel 7 menunjukkan semua indikator MPA dalam melakukan penyuluhan berkategori "Tinggi". Nilai tersebut menjelaskan aktifnya kegiatan penyuluhan penguatan kelembagaan yang dilakukan pada MPA terus memperbaiki meningkatkan dari segi manajemen, sumber daya manusia maupun fasilitas yang dibutuhkan. Skor terendah terdapat pada indikator penyuluhan bersama petugas unit, hal ini dikarenakan MPA desa yang ada di Kecamatan Bukit Batu tidak semua aktif dan banyak yang baru dirikan pada tahun 2014 karena bencana asap yang sangat besar bersumber dari Kecamatan Bukit Batu. Hanya MPA Desa Sepahat dan Desa Tanjung Leban yang dari tahun 2009 dibentuk dan aktif sampai sekarang.MPA Desa Sepahat dan Tanjung Leban juga aktif memberikan penyuluhan ke desa-desa lain di Kecamatan Bukit Batu.

\section{d. Melakukan Pertemuan}

Masyarakat Peduli Api dalam peran melakukan pertemuan berguna untuk pengembangan kemampuan dan pengalaman di lapangan dalam menjaga hutan dari ancaman kebakaran.Hasil penelitian MPA dalam melakukan pertemuan untuk lebih jelasnya dapat dilihat pada Tabel 8 .

69 | Peran Kelompok Tani Dan Masyarakat Peduli Api (MPA) Dalam Mengelola Dan Mencegah Kebakaran Lahan Di Kecamatan Bukit Batu Kabupaten Bengkalis 
Tabel 8. MPA melakukan pertemuan di Kecamatan Bukit Batu

\begin{tabular}{llcc}
\hline No & \multicolumn{1}{c}{ Indikator } & Skor & Kategori \\
\hline 1 & Pertemuan rutin dalam rangka kelembagaan & 2,73 & Tinggi \\
2 & Aktif membantu manggala agni & 2,56 & Tinggi \\
3 & Mengikuti pelatihan pengendalian kebakaran & 2,61 & Tinggi \\
4 & Menyusun peta desa rawan terbakar & 3.00 & Tinggi \\
5 & Simulasi pemadaman & 2,68 & Tinggi \\
\hline & Rata-rata & 2,71 & Tinggi \\
\hline
\end{tabular}

Tabel 8 menunjukkan seluruh indikator MPA dalam melakukan pertemuan berkategori "Tinggi". Nilai tersebut menjelaskan bahwa MPA sudah baik dalam melakukan pertemuan seperti melakukan pertemuan bersama penyuluh, kelembagaan dari pemerintah BNPB, BPBD dan lain lain.Skor tertinggi ada pada indikator yang sama yaitu menyusun peta desa rawan kebakaran, hal ini menjelaskan bahwa MPA sangat penting dan diharuskan membuat peta desa rawan terbakar karena itu berguna sebagai koordinasi anggota di lapangan dalam berpatroli. Skor terendah pada indikator ikut aktif membantu manggala agni dalam pemadaman kebakaran lahan, hal ini menjelaskan bahwa melakukan pemadaman merupakan tugas utama MPA dan aktif membantu manggala agni sudah pasti dilakukan tetapi manggala agni hanya ikut berpartisipasi ketika kebakaran besar terjadi.

\section{Kesimpulan}

\section{KESIMPULAN DAN SARAN}

1. Kebakaran lahan di Desa Sepahat dan Tanjung Leban Kecamatan Bukit Batu Kabupaten Bengkalis disebabkan oleh faktor biofisik, faktor ekonomi dan faktor sosial budaya. Faktor biofisik meliputi cuaca atau iklim, angin, berlahan gambut, lahan bekas terbakar.Faktor ekonomi meliputi pendapatan keluarga, status kepemilikan tanah dan luas lahan.Faktor sosial budaya meliputi adalah tingkat pendidikan, tradisi budaya, respon pemerintah dan lemah hukum.

2. Peran kelompoktani di Desa Sepahat dan Tanjung Leban dalam mengelola dan mencegah kebakaran lahan berkategori "Tinggi", hal ini terlihat dari pengelolaan lahan tidak dengan cara membakar, dan mengganti komoditi kelapa sawit menjadi nenas yang sesuai dengan jenis lahan tidak mudah terbakar. Nenas juga ditanam menjadi pagar terhadap api di kebun kelapa sawit.Kegiatan kerjasama dengan kelompoktani dengan MPA juga terlaksanakan seperti dalam pembuatan sekat kanal dan sumur bor.

70 | Peran Kelompok Tani Dan Masyarakat Peduli Api (MPA) Dalam Mengelola Dan Mencegah Kebakaran Lahan Di Kecamatan Bukit Batu Kabupaten Bengkalis 
3. Peran MPA di Kecamatan Bukit Batu dalam mencegah dan penanggulangan kebakaran berkategori "Tinggi", hal ini terlihat dari berkurangnya titik api dan luas kebakaran di Kecamatan Bukit Batu sepanjang tahun 2015. Kegiatan MPA dalam mencegah kebakaran seperti patroli lapangan yang dilakukan setiap hari dari pagi sampai sore, pembuatan sekat kanal, sumur bor, kolam penampungan air di titik-titik rawan terbakar.

\section{Saran}

1. Diharapkan Pemerintah Provinsi Riau lebih serius dalam penanganan kebakaran hutan dan lahan, dengan menambah anggaran penanggulangan bencana daerah.

2. Kebijakan dalam penanganan kebakaran hutan dan lahan sebaiknya lebih difokuskan kepada tindakan pencegahan daripada penanganan dengan menggunakan informasi prediksi iklim dan penyimpangan serta dampaknya terhadap resiko kebakaran hutan dan lahan sebagai salah satu bagian dalam sistem informasiuntuk deteksi/peringatan dini kebakaran hutan dan lahan.

3. Diharapkan setiap desa di Provinsi Riau yang hutan danlahan luas memiliki MPA seperti Desa Sepahat dan Desa Tanjung Leban agar lebih siap dalam mencegah dan menanggulangi permasalahan kebakaran hutan dan lahan.

\section{DAFTAR PUSTAKA}

Badan Pusat Statistik Provinsi Riau. 2015. Bengkalis dalam Angka. BPS. Pekanbaru.

Suwondo dan Haris Gunawan. 2015. Pengelolaan Lingkungan Berkelanjutan. Universitas Riau Press. Pekanbaru.

Garjita, I Putu. 2014. Strategi Pemberdayaan Masyarakat Kelompok Tani Hutan Ngudi Makmur di Sekitar Kawasan Taman Nasional Gunung Merapi. Jurnal EKOSAINS. Vol VI. No. 1 Maret 2014. Universitas Diponegoro. Semarang.

Limin, S. 2006. Pemanfaatan Lahan Gambut dan Permasalahannya. Workshop Gambut Kerjasama antara Badan Pengkajian dan Penerapan Teknologi (BPPT) dan Kementerian Koordinator Kesejahteraan Rakyat. Jakarta, 22 November 2006

Peraturan Direktur Jenderal Perlindungan Hutan dan Konservasi Alam No : P.2/IV-SET/2014 Tentang Pembentukan dan Pembinaan Masyarakat Peduli Api.

71 | Peran Kelompok Tani Dan Masyarakat Peduli Api (MPA) Dalam Mengelola Dan Mencegah Kebakaran Lahan Di Kecamatan Bukit Batu Kabupaten Bengkalis 